Journal of Engineering and Applied Sciences 14 (20): 7743-7755, 2019

ISSN: 1816-949X

(C) Medwell Journals, 2019

\title{
The Adsorption of Cadmium, Nickel, Zinc, Copper and Lead from Wastewater using Tea Fiber Waste
}

\author{
${ }^{1}$ Milica Nikolic, ${ }^{2}$ Rohan Jeffry Robert and ${ }^{2}$ C.R. Girish \\ ${ }^{1}$ Department of Chemical Engineering, Faculty of Technology and Metallurgy, \\ University of Belgrade, Belgrade, Serbia \\ ${ }^{2}$ Department of Chemical Engineering, Manipal Institute of Technology, \\ Manipal Academy of Higher Education, Manipal, Karnataka, India \\ girishcr1@rediffmail.com
}

\begin{abstract}
The feasibility of tea fiber waste to remove cadmium, nickel, zinc, copper and lead from wastewater was studied in the present research. The tea fiber was treated with ferric oxide and nitric acid solution and the properties like surface area, pore volume and particle size were improved. The surface characteristics of the adsorbent was determined using SEM and FTIR analysis. Isotherm models such as Langmuir, Freundlich, Flory Huggins, Temkin and Dubinin Radushkevich models were used to investigate the isotherm data in the single solution mode. The data were matching better with the Freundlich model compared to other models. The adsorbent treated with ferric oxide was showing better in comparison with the adsorbent treated with nitric acid mainly because of surface properties. The interaction mechanism in the quinary solution showed synergism for cadmium, zinc and lead and antagonism for nickel and copper.
\end{abstract}

Key words: Tea fiber, surface morphology, toxic metal, isotherm, multicomponent, interaction

\section{INTRODUCTION}

Water is considered as one of the resource required for all the living species in the environment (Rathinam et al., 2019). The increase in global population is leading to rapid industrialization and urbanization and thus, releases wastewater into the aquatic system and agricultural land (Mohan, 2014; Prelot et al., 2018). At the same time, disposing of the industrial waste in an irregular way, especially, in developing countries results in environmental issues. This wastewater contains all the pollutants like toxic metals, dyes and organic compounds (Verma and Sarkar, 2018). Hence, the industrial wastewater is a multicomponent mixture having different pollutants and the treatment of these components is a major challenge (Costa et al., 2018). The components will interact and compete among each other and it is important to understand the overall behavior of the system (Loganathan et al., 2018). Also by studying the competitive interaction (synergistic or antagonistic) among the pollutants, the mobility of these components can be understood and treatment can be implemented effectively (Du et al., 2018.) Toxic metals which are the major pollutants in wastewater are having adverse effects on the human health and aquatic system (Rathinam et al., 2019; Wang and Chen, 2018). Also because of the non-biodegradable and high mobile nature of these metals in the environment, it enters the food chain and effects the ecosystem (Arim et al., 2018; Niu et al., 2018). The environmental protection agencies, defines some of the toxic metals copper, nickel, zinc, cadmium and lead as priority pollutants because of its harmful effects (Anna et al., 2015). Thus, the current research investigates treatment of these metals from multicomponent solution.

Copper is one of the toxic metal which is found in the wastewater released from industries like electroplating, hydrometallurgy, mining, metal coating, electroplating and painting industries (Nashtifan et al., 2017; Zhou et al., 2017). It is considered to be one of the transition metal ion required for functioning of biological processes in the human body. It is necessary for functioning of enzymes and development of bones for the human beings. But however, when the metal quantity exceeds the maximum limit, it results in carcinogenic problems, effects central nervous system, respiratory system and causes gastrointestinal diseases and anaemia (Nashtifan et al., 2017; Zhou et al., 2017). The presence of metal in the water bodies also affects the aquatic life and the environment. As per the World Health Organization the allowable concentration of copper in drinking water should be lower than $2.0 \mathrm{mg} / \mathrm{L}$ and the Indian standards

Corresponding Author: C.R. Girish, Department of Chemical Engineering, Manipal Institute of Technology, Manipal Academy of Higher Education, Manipal, Karnataka, India, girishcr1@rediffmail.com 
have recommended the permissible concentration of copper as $0.05 \mathrm{mg} / \mathrm{L}$ in the water sources (Chatterjee et al., 2017; Zhou et al., 2017).

Zinc is one of the important metal used in industries such as ceramics, rubber, fabrics, metal coating for corrosion prevention, mining manufacturing and battery. Its salts are used for preparing catalysts, wood preservatives and photographic paper. Zinc is present in the wastewater released from acid mines and galvanizing industries. Baig et al. (2009), Chatterrjee et al. (2017) and Ray et al. (2018) World Health Organization defines the allowable concentration of zinc in the drinking water $<5.0$ ppm (Baig et al., 2009; Chatterjee et al., 2017). The excess quantity of zinc causes various harmful effects to aquatic bodies and the human beings. It causes depression, nausea, diarrhea, lethargy, restlessness, skin irritations and vomiting (Ray et al., 2018; Sukpreabprom et al., 2015). It is non-biodegradable and enters the plant cells, animals and humans through food chain and causes adverse effects (Ray et al., 2018).

Cadmium is associated from industries like mining, battery, stabilizers, fertilizers, enameling and plating industries (Bozorgi et al., 2018). As per the environmental regulation agencies, the permissible level of cadmium in drinking water is $0.001 \mathrm{mg} / \mathrm{L}$ (Belyakova et al., 2014). It is non-biodegradable compound that enters the human metabolism system through food chain (Sukpreabprom et al., 2015). Its excess to human beings causes anemia, dis-functioning of liver, kidneys, lungs, cancer, skeleton damage and results in other problems memory deterioration (Belyakova et al., 2014).

Lead is an important pollutant from the paints, explosives, photographic materials, glass operating, plating, petrochemical, oil, pigments and rubber industries (Kakavandi et al., 2016; Kavand et al., 2014). Higher exposure of lead to human body causes mental retardation, encephalopathy, kidney damage, gastrointestinal damage, liver damage, hypertension and reduces haeglobin production (Hossain et al., 2014; Mohan 2014). It should be taken precaution that the concentration of $0.1 \mathrm{mg} / \mathrm{L}$ of lead into water bodies allowed as per the environmental regulations (Kavand et al., 2014).

Nickel is one of the toxic metal released from industries such as battery, electroplating, plating, paint, mining, metallurgy, battery and fertilizer industries (Arim et al., 2018; Nashtifan et al., 2017). The wastewater from the metal plating industries contains nickel in the range $6-12 \mathrm{mg} / \mathrm{L}$ (Kavand et al., 2014). At higher concentration, nickel is having harmful effects such as gastrointestinal irritation and lung, kidney problems, skin dermatitis, headaches, dizziness, chest pain and other health problems (Kavand et al., 2014; Zeledon-Toruno et al., 2005). The maximum allowable concentration of nickel in drinking water as per environmental protection agencies is $0.1 \mathrm{mg} / \mathrm{L}$ (Baig et al., 2009).

A large number of treatment methods such as chemical precipitation, electrolysis, membrane separation, ion exchange, flotation, coagulation and adsorption are used for treating toxic metals from wastewater (Bozorgi et al., 2018; He et al., 2018a, b). Among the above methods, adsorption using adsorbent is considered to be effective method for treating toxic metals from aqueous solution (Sreedharan et al., 2017). It has greater efficiency for removing variety of pollutants, easy to operate, economically feasible (Zhou et al., 2017). It has the advantages of simplicity in process design and can selectively remove specific pollutants from a multicomponent mixture (Xu et al., 2018).

The adsorbent produced from non-renewable sources has higher adsorption capacity. But considering the cost of the adsorbent there is a need to produce the adsorbent from low cost agricultural waste materials (Da-Gama et al., 2018). Therefore, in the present study an effort has been made to produce the adsorbent from tea fibre waste. Thus, the adsorbent is used to remove the toxic metals copper, nickel, zinc, cadmium and lead from wastewater.

\section{MATERIALS AND METHODS}

Chemicals used: The chemicals nickel chloride hexahydrate (Merck India Limited), cadmium nitrate tetrahydrate (Finar Ltd), lead nitrate (Finar Ltd), cupric nitrate trihydrate (Finar Ltd) and zinc sulphate heptahydrate (Finar Ltd) were used for the preparing the solutions. The other chemicals ferric oxide red (Finar Ltd), nitric acid (Fischer Scientific Ltd), sulphuric acid (Merck India Limited) and sodium hydroxide pellets (Fischer Scientific Limited) were used in the experiments.

Adsorbent preparation: The tea waste fibres were obtained from tea plantation from Sivasagar, Assam and used for adsorbent preparation. The material was thoroughly washed with distilled water to remove the dirt particles and later the slurry was stirred with mechanical stirrer and then allowed to settle. After the settling process, the top layer containing water with the dirt particles are separated. The bottom layer having the material was dried in oven at $110^{\circ} \mathrm{C}$ for 2 days to remove the moisture content. The slurry was stirred every $3 \mathrm{~h}$ and the drying process was checked. Later $50 \mathrm{~g}$ of dried powder was mixed separately with $200 \mathrm{~mL}$ of $0.2 \mathrm{M}$ nitric acid and $200 \mathrm{~mL}$ of $0.1 \mathrm{M}$ ferric oxide solution for $20 \mathrm{~min}$. Then the slurry formed was heated inside muffle furnace at $550^{\circ} \mathrm{C}$ for $1 \mathrm{~h}$ and $550^{\circ} \mathrm{C}$ for $1.5 \mathrm{~h}$ for nitric acid solution and ferric oxide solution, respectively. Later, the dried 
samples were washed with water to remove all the excess chemicals. The washing process was carried out continuously, so that, the $\mathrm{pH}$ value comes to $7-8$ (Moreno-Castilla, 2004). Finally, the water content is removed, the slurry is dried in the oven at $80^{\circ} \mathrm{C}$ and used for the experiments.

Characterization of the adsorbent: The proximate analysis of the raw material was carried out to calculate the moisture content, volatile matter, ash content and fixed carbon using standard procedure (APHA et al., 1989). The pore volume and surface area were measured with BET apparatus (Smart Instruments, India). The particle size was found using particle size analyzer (CLAS 1064, France). The functional groups existing on the adsorbent surface were analyzed using Fourier Transform Infrared spectroscopy (FTIR) instrument, Shimadzu, Japan. The surface structure of the adsorbent was obtained by Scanning Electron Microscopy (SEM), Zeiss Company, Germany. The confirmation of the presence of metal ions on the surface were carried out using Energy Dispersive X-ray (EDX).

Batch experiments: The batch studies were performed in $250 \mathrm{~mL}$ flask having $200 \mathrm{~mL}$ of different pollutants like copper, zinc, nickel, cadmium and lead. The metal solutions were prepared in the concentration range varying from $5-25 \mathrm{mg} / \mathrm{L}$. The isotherm experiments in the single solution mode were conducted by taking the different solutes individually in the concentration range of $5-25 \mathrm{mg} / \mathrm{L}$ of all the metals copper, zinc, nickel, cadmium and lead. The adsorption studies were carried out separately by mixing the solutions with $0.5 \mathrm{~g}$ of the ferric oxide and nitric acid treated adsorbent at $\mathrm{pH} 7,28^{\circ} \mathrm{C}$. It is subjected to agitation in a shaker at a stirring speed of $125 \mathrm{rpm}$ for the equilibrium time of $12 \mathrm{~h}$. The multicomponent studies were conducted by combining all the pollutants in quinary solution mode. The quinary solution consists of $40 \mathrm{~mL}$ of $25 \mathrm{mg} / \mathrm{L}$ concentration solution of all the five components in the $250 \mathrm{~mL}$ flask. The experimental conditions were maintained similar as that of the single solution mode experiments. The flasks were agitated inside the shaker till the equilibrium time. Then the residual concentration of the solutes in the multicomponent solutions were analyzed with the help of atomic absorption spectrophotometer (Thermo Scientific, Australia). The concentration of lead, cadmium, nickel, copper and zinc were measured at a wavelength of 217 , $228.8,232.1,324.8$ and $213.9 \mathrm{~nm}$, respectively.

\section{RESULTS AND DISCUSSION}

\section{Adsorbent characterization}

Surface properties of the adsorbent: The proximate analysis of the raw material as given in Table 1 showed
Table 1: Proximate analy sis of the raw material

\begin{tabular}{lc}
\hline Parameters & Values (\%) \\
\hline Moisture & 7.91 \\
Ash content & 22.09 \\
Volatile matter & 21.82 \\
Fixed carbon content & 48.18 \\
\hline
\end{tabular}

Table 2: The surface properties of the treated adsorbents

\begin{tabular}{lcr}
\hline Veriables & $\begin{array}{c}\text { Adsorbent (ferric } \\
\text { oxide treated) }\end{array}$ & $\begin{array}{c}\text { Adsorbent (nitric } \\
\text { acid treated) }\end{array}$ \\
\hline Surface area $\left(\mathrm{m}^{2} / \mathrm{g}\right)$ & 25.2000 & 19.8900 \\
Pore volume $\left(\mathrm{cm}^{3} / \mathrm{g}\right)$ & 00.0127 & 00.0066 \\
Particle size $(\mu \mathrm{m})$ & 106.3100 & 109.8500 \\
\hline
\end{tabular}

fixed carbon content of $48.18 \%$ suggesting that the materia was suitable for the adsorption process and potential capacity to remove the pollutant (Elizalde-Gonzalez and Hernandez-Montoya, 2009). By treating the adsorbent with ferric oxide and nitric acid solution the surface properties such as the pore volume and pore diameter were improved (Jung et al., 2017). The average particle size was obtained as 106.31 and $109.85 \mu \mathrm{m}$ for adsorbent treated with ferric oxide and adsorbent treated with nitric acid, respectively which shows that it assists in the accumulation of the pollutant. The surface properties for both the adsorbent treated with ferric oxide and adsorbent treated with nitric acid obtained are shown in Table 2. These values were promising and suggests that the adsorbent have capability in accommodating larger number of solute molecules in the pores of the adsorbent (Salman and Hameed, 2010).

FTIR analysis of the adsorbent: The FTIR spectra of the ferric oxide treated and nitric acid treated adsorbent before and after adsorption are given in Fig. 1-4. In the ferric oxide treated various peaks are formed are discussed below. The peak at $570.93 \mathrm{~cm}^{-1}$ was assigned to vibrations of $\mathrm{Fe}-\mathrm{O}$ bonding of iron oxide (Shirani et al., 2014). The $\mathrm{C}=\mathrm{C}$ bond of alkynes is shown for the peak at 2208.49 and $2212.35 \mathrm{~cm}^{-1}$. The peak at 331.07 and $3313.71 \mathrm{~cm}^{-1}$ are because of $\mathrm{O}-\mathrm{H}$ vibrations of carboxylic group (He et al., 2017). The peak at 1598.9 and $1593.2 \mathrm{~cm}^{-1}$ are ascribed to hydrogen bonding of carboxyl group. (Anirudhan et al., 2009). The $\mathrm{C}-\mathrm{H}$ functional group peak was observed at $3072.9 \mathrm{~cm}^{-1}$ (Gupta and Balomajumder, 2017). The formation of these bonds on the adsorbent surface and the changes in the peaks of these functional groups were responsible for the adsorption of pollutant on the adsorbent surface.

In the adsorbent treated with nitric acid, the peak found at $3547.09 \mathrm{~cm}^{-1}$ is because of $\mathrm{N}-\mathrm{H}$ bonding of amines proving the formation of amino group on the treated carbon. The peak obtained at 1128.36 and $1134.14 \mathrm{~cm}^{-1}$ are due to C-O stretching mode (Kumar et al., 2018). The peak at $3350.35 \mathrm{~cm}^{-1}$ is because of hydroxyl group obtained from the cellulose group (Costa et al., 2018). 


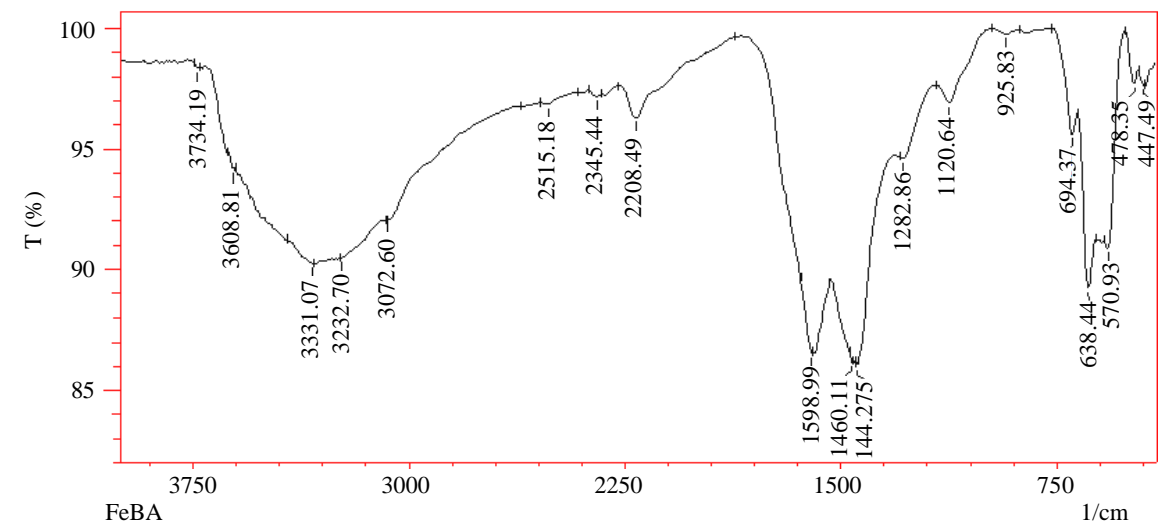

Fig. 1: FTIR analysis of the adsorbent treated with ferric oxide before adsorption

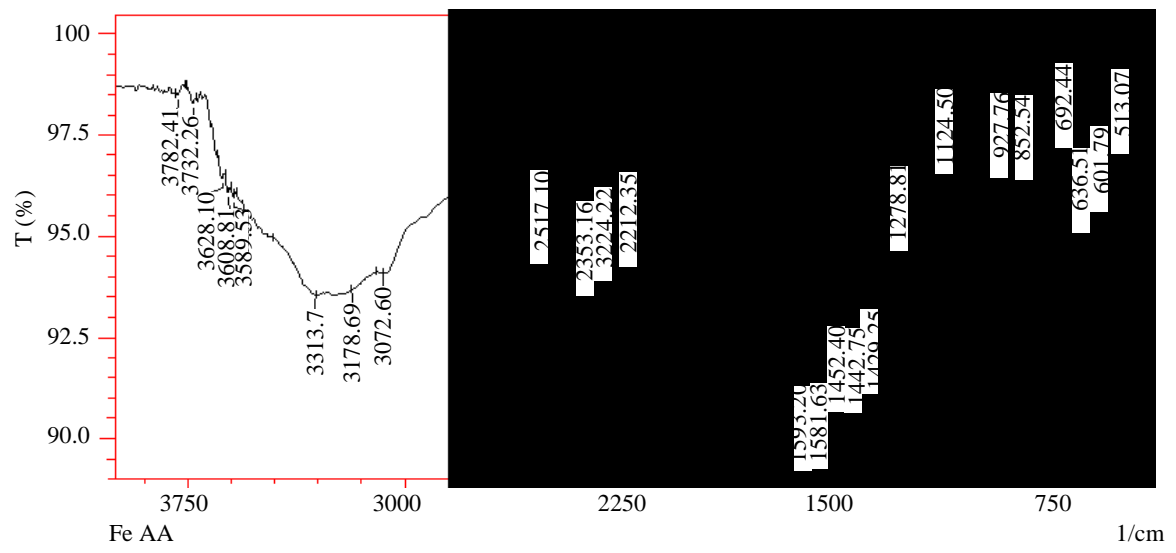

Fig. 2: FTIR analysis of the adsorbent treated with ferric oxide after adsorption

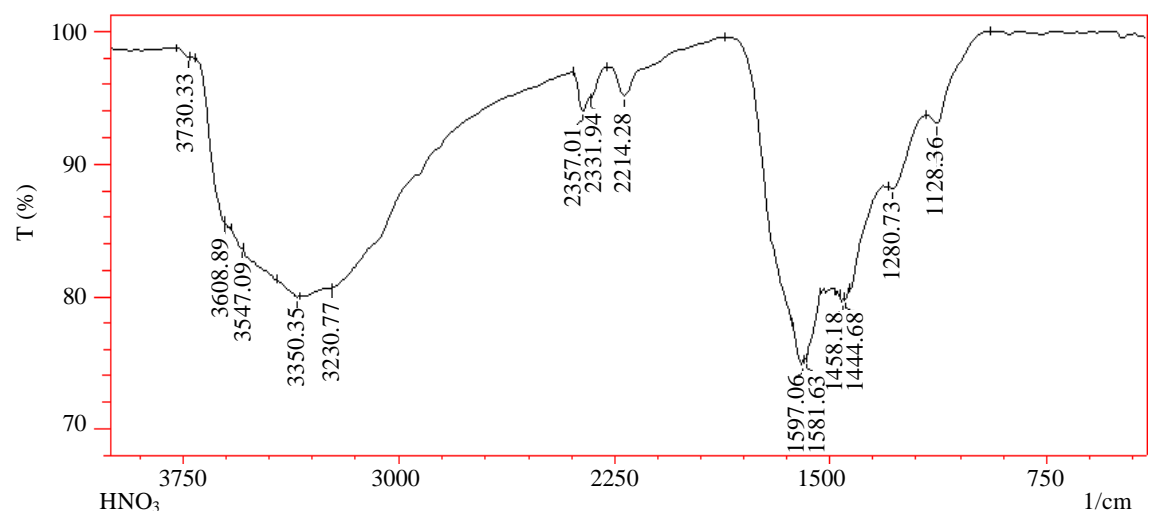

Fig. 3: FTIR analysis of the adsorbent treated with nitric acid before adsorption

The peak formed at 1581.63 and $1579.70 \mathrm{~cm}^{-1}$ signifies the N-H bond formed in the adsorbent material (Shirani et al., 2014) and the band at $1597 \mathrm{~cm}^{-1}$ is from the $\mathrm{C}-\mathrm{C}$ stretching of polyaromatic $\mathrm{C}=\mathrm{C}$ peak (Park et al., 2010).
SEM and EDX analysis of the adsorbent: SEM is a well know tool used for investigating the morphology and surface characterization of the material (Sathishkumar et al., 2007). It is also used study other aspects such as shape, porous nature and the size 


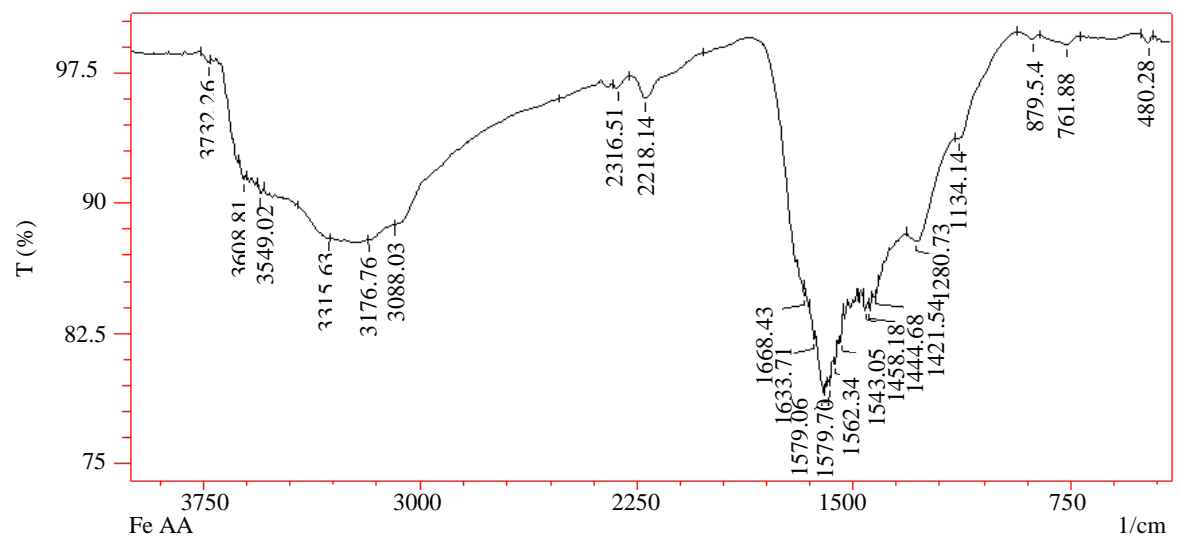

Fig. 4: FTIR analysis of the adsorbent treated with nitric acid after adsorption

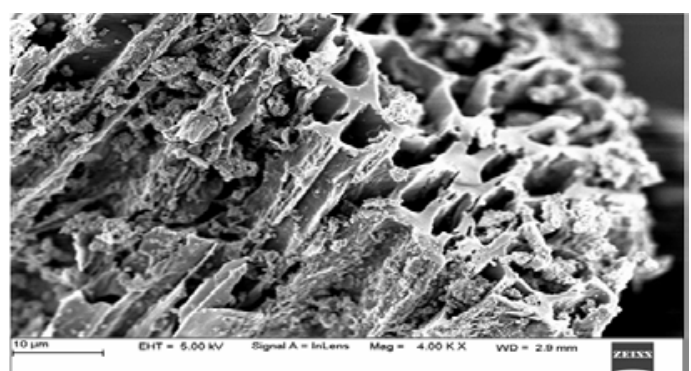

Fig. 5: SEM image of the adsorbent treated with ferric oxide before adsorption

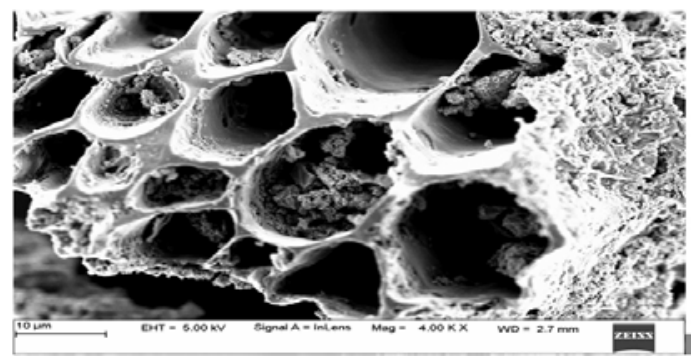

Fig. 6: SEM image of the adsorbent treated with ferric oxide after adsorption

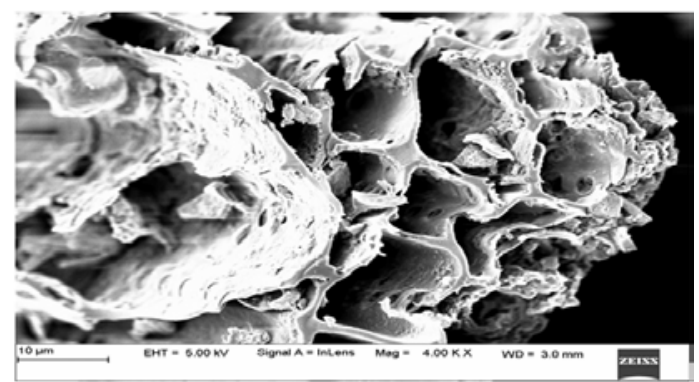

Fig. 7: SEM image of the adsorbent treated with nitric acid before adsorption

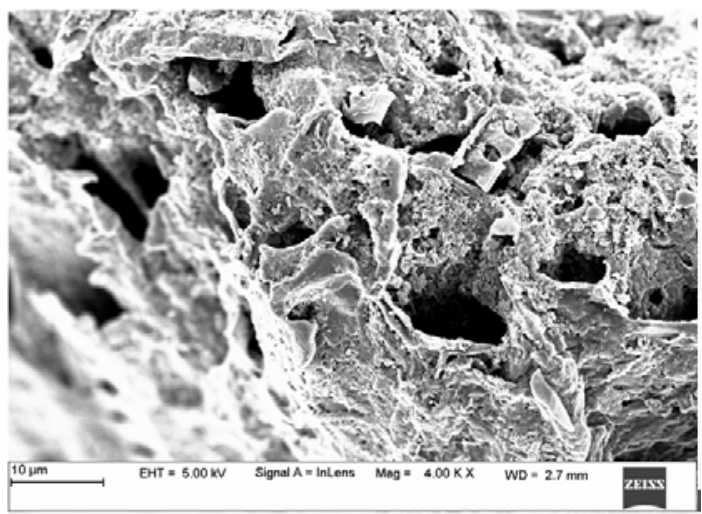

Fig. 8: SEM image of the adsorbent treated with nitric acid after adsorption

distribution of the molecules (Achak et al., 2009). The surface morphological images of the adsorbent treated with ferric oxide solution and nitric acid solution are represented in Fig. 5-8.

It was found from the morphological images that the adsorbents treated with ferric oxide and nitric acid were having different sized pores which will be beneficial for the adsorption process (Hameed, 2009). It was also observed that the adsorbent particles were irregularly shaped in the porous structure. After the adsorption process a notable change in the adsorbent surface was observed. It was found that the surface was heterogeneous in nature signifying that the adsorbent pores were occupied with pollutant molecules (Achak et al., 2009; Arami et al., 2005).

Energy-Dispersive X-ray spectroscopy (EDX) analysis was performed to detect the presence of metal ions on the surface of adsorbent (Werkneh et al., 2018). The EDX analysis of the adsorbents before and after the adsorption of the pollutants are shown in Fig. 9-12. The EDX analysis of the adsorbents before adsorption shows various peaks for the metal ions such as $\mathrm{Ca}^{+}, \mathrm{K}^{+}, \mathrm{Mg}^{2+}$, 


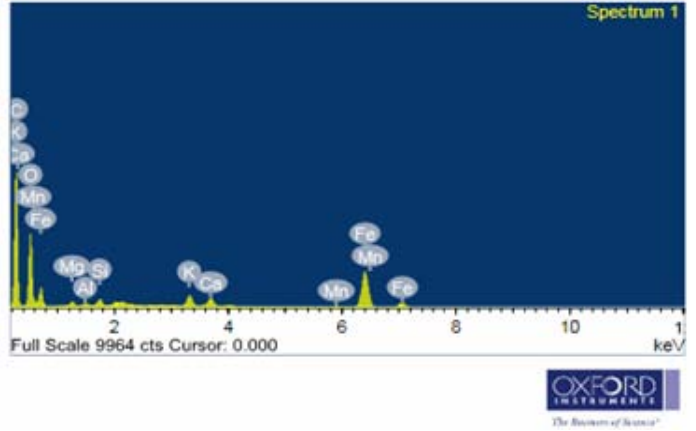

Fig. 9: EDX analysis of the ferric oxide treated adsorbent before adsorption

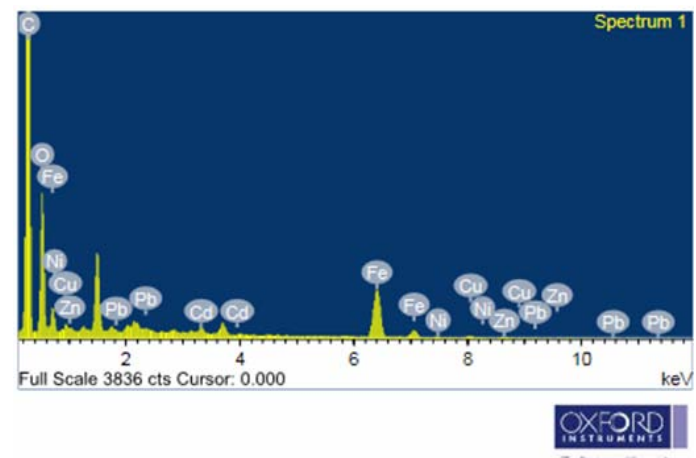

Fig. 10: EDX analysis of the ferric oxide treated adsorbent after adsorption
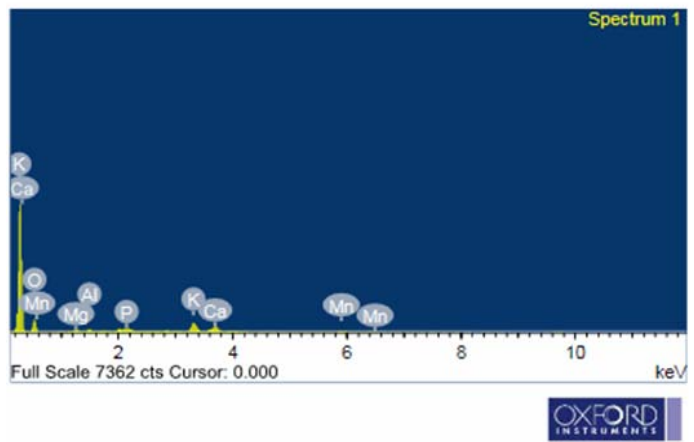

Fig. 11: EDX analysis of the nitric acid treated adsorbent before adsorption

$\mathrm{Mn}^{2+}, \mathrm{Fe}^{2+}, \mathrm{P}^{3+}$ which were found to be present as plant nutrients in the tea fibre waste. After the adsorption clear peaks were obtained for the metal ions such as $\mathrm{Cd}^{2+}$, $\mathrm{Zn}^{2+}, \mathrm{Ni}^{2+}, \mathrm{Cu}^{2+}$ and $\mathrm{Pb}^{2+}$ on the adsorbent. This signifies that the metal ions were adsorbed onto the adsorbent surface through the ion exchange process (Iqbal et al., 2009; Lu et al., 2013).

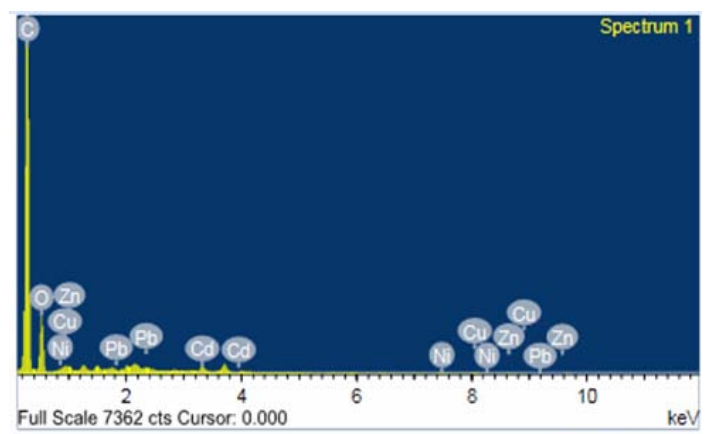

OXFORD

Fig. 12: EDX analysis of the nitric acid treated adsorbent after adsorption

Adsorption isotherm: The adsorption isotherm gives the description to understand how the adsorbate molecules distributes on the surface of the adsorbent and the affinity of the solute to the adsorbent at equilibrium (Verma and Sarkar, 2018). It also explains the interaction behavior of the adsorbent and the solute molecule (Zhou et al., 2017). Different isotherm models available from the literature for used for isotherm studies. The prominent isotherm models like Langmuir, Freundlich, Temkin, Dubinin-Radushkevich (D-R) and Flory-Huggins isotherm models were employed to evaluate the mechanism of adsorption.

Langmuir isotherm: The model is obtained by assuming that the adsorbent has active sites distributed uniformly all over the surface and the binding sites are limited (Liu et al., 2010). It explains that once the active site is occupied by the pollutant molecule, the intermolecular forces decreases and there is no provision for the other solute molecule to adsorb on the surface resulting in monolayer adsorption (Mohammad-Rezaei and Jaymand, 2019).

The model also states that the energy of sorption on each of the active sites is uniform (Babaee et al., 2018). The model is given in the simplified form as:

$$
\frac{\mathrm{C}_{\text {eq }}}{\mathrm{q}_{\mathrm{eq}}}=\frac{\mathrm{C}_{\mathrm{eq}}}{\mathrm{q}_{\mathrm{mn}}}+\frac{1}{\mathrm{k}_{\mathrm{lg} \mathrm{gmn}}}
$$

Where:

$\mathrm{q}_{\mathrm{mn}}(\mathrm{mg} / \mathrm{g})=$ The maximum adsorption capacity

$\mathrm{k}_{1 \mathrm{~g}}(\mathrm{~L} / \mathrm{mg}) \quad=$ The constant related to affinity of the pollutant to the adsorbent

$\mathrm{q}_{\text {eq }}(\mathrm{mg} / \mathrm{g})=$ The adsorption capacity and solute and $\mathrm{C}_{\mathrm{eq}}(\mathrm{mg} / \mathrm{L}) \quad$ concentration at equilibrium conditions 
The model parameters are obtained by plotting $\mathrm{C}_{\mathrm{eq}} / \mathrm{q}_{\text {eq }}$ against $\mathrm{C}_{\text {eq }}$.

Freundlich isotherm: The model can be applied to adsorption processes which occurs on the heterogeneous surface and the energy distribution is not uniform. The solute molecules gets occupied on the solid surface in form of multilayers (Park et al., 2010). It also, shows exponential decrease of adsorption energy with the coverage on the binding sites (Sarkar and Acharya, 2006). The equation is represented in the linear form as:

$$
\log \mathrm{q}_{\text {eq }}=\log \mathrm{k}_{\mathrm{f}}+(1 / \mathrm{n}) \log \mathrm{C}_{\text {eq }}
$$

$\mathrm{k}_{\mathrm{f}}$ the Freundlich constant and $\mathrm{n}$ denotes the adsorption intensity. The value of $\mathrm{n}>1$ signifies that the adsorption is favourable and better interaction of the adsorbate to the adsorbent surface (Bozorgi et al., 2018; Li et al., 2009; Liu et al., 2019). The model constants are evaluated from the plot of $\log q_{\text {eq }} v / s \log C_{\text {eq }}$.

Temkin isotherm: The isotherm model takes into the interactions between the solute and the adsorbent molecule during the adsorption process. It also suggests that the adsorption energy of the molecules in the various layers decreases linearly as the solute molecules are occupied on the active sites (Yousef et al., 2011). It is represented as:

$$
\mathrm{q}_{\mathrm{eq}}=\mathrm{B}_{\mathrm{T}} \ln \mathrm{A}_{\mathrm{T}}+\mathrm{B}_{\mathrm{T}} \ln \mathrm{C}_{\mathrm{eq}}
$$

$\mathrm{A}_{\mathrm{T}}(\mathrm{L} / \mathrm{mg})$ the model parameters and $\mathrm{B}_{\mathrm{T}}(\mathrm{J} / \mathrm{mol})$ the constant related to heat of sorption. The parameters are evaluated by plotting $\mathrm{q}_{\mathrm{eq}} \mathrm{v} / \mathrm{s} \ln \mathrm{C}_{\mathrm{eq}}$.

Flory-Huggins model: The Flory-Huggins (FH) model is employed for studying the extent of surface coverage characteristics of the pollutant on the solid surface and it describes the feasibility of the adsorption process (Foo and Hameed, 2010). It is written in the simplified form as:

$$
\log \left(\theta_{\mathrm{s}} / \mathrm{C}_{\mathrm{o}}\right)=\log \mathrm{k}_{\mathrm{fh}}+\mathrm{n}_{\mathrm{fh}} \log \left(1-\theta_{\mathrm{s}}\right)
$$

$\mathrm{k}_{\mathrm{fh}}$ equilibrium constant, $\mathrm{n}_{\mathrm{fh}}$ model constant $\theta_{\mathrm{s}}$ the surface coverage value is obtained by:

$$
\theta_{\mathrm{s}}=1-\frac{\mathrm{C}_{\mathrm{eq}}}{\mathrm{C}_{\mathrm{o}}}
$$

Dubinin-Radushkevich model: The DubininRadushkevich (D-R) model is helpful in evaluating the apparent free energy of adsorption and is represented as (Kilic et al., 2011; Rathinam et al., 2019)

$$
\mathrm{q}_{\mathrm{eq}}=\mathrm{q}_{\mathrm{dr}} \mathrm{e}^{. \mathrm{ex}^{2}}
$$

$\beta$ the sorption energy constant $(\mathrm{mol})^{2} \mathrm{~kJ}^{2}, \mathrm{q}_{\mathrm{dr}}$ the D-R capacity $\left(\mathrm{mg} / \mathrm{g}\right.$ ) and by plotting $\operatorname{lnq}_{\mathrm{eq}} \mathrm{v} / \mathrm{s} \epsilon^{2}$ the model constants $\beta$ and $\mathrm{q}_{\mathrm{dr}}$ are obtained. $\epsilon$ the Polanyi potential which is calculated using:

$$
\in=\mathrm{RT} \ln \left(1+\frac{1}{\mathrm{C}_{\mathrm{eq}}}\right)
$$

The mean free energy is obtained using the formula:

$$
\mathrm{E}=\frac{1}{\sqrt{2 \times \beta}}
$$

The factor $\mathrm{E}(\mathrm{kJ} / \mathrm{mol})$ shows the energy required to transfer $1 \mathrm{~mol}$ of the solute to the adsorbent surface from infinity in the solution (Omidinasab et al., 2018). The values of $\mathrm{E}$ between 8 and $16 \mathrm{~kJ} / \mathrm{mol}$ shows that the process is chemical adsorption and the $\mathrm{E}$ value lower than $8 \mathrm{~kJ} / \mathrm{mol}$ signifies the interaction mechanism is physical in nature (Kumar et al., 2018; Omidinasab et al., 2018).

The isotherm experiments were conducted in the concentration ranges of $5,10,15,20$ and $25 \mathrm{mg} / \mathrm{L}$ for various metal ions. The different isotherm models were investigated with respect to single component equilibrium data. The calculated model parameters with the obtained regression coefficient values for iron treated and nitric acid treated adsorbents are given Table 3-6. The results obtained showed that Freundlich model fits better with the experimental data and it signified that adsorption of the solute on the adsorbent is physical and it takes place in multilayers. The Langmuir constant $\mathrm{k}_{\mathrm{lg}}$ was evaluated which shows the affinity of solute molecules to the adsorbent (Verma and Sarkar, 2018). The values of the monolayer adsorption capacities obtained from the Langmuir model are represented in Table 3. The adsorption intensity $\mathrm{n}$ shows the types of process. The value of $n>1$ indicates that the adsorption is physical in nature. The process is chemical in nature if the values of $n$ is $<1$. Thus, from the obtained values of $\mathrm{n}$ it can be inferred that the accumulation of the pollutant 
Table 3: The Langmuir model parameters obtained for both the adsorbents Adsorbent (ferric oxide treated) Adsorbent (nitric acid treated)

\begin{tabular}{lllllll} 
Elements & $\begin{array}{l}\mathrm{q}_{\mathrm{mn}} \\
(\mathrm{mg} / \mathrm{g})\end{array}$ & $\begin{array}{l}\mathrm{k}_{\mathrm{lg}} \\
(\mathrm{L} / \mathrm{mg})\end{array}$ & $\mathrm{R}^{2}$ & $\begin{array}{l}\mathrm{q}_{\mathrm{mn}} \\
(\mathrm{mg} / \mathrm{g})\end{array}$ & $\begin{array}{l}\mathrm{k}_{\mathrm{lg}} \\
(\mathrm{L} / \mathrm{mg})\end{array}$ & $\mathrm{R}^{2}$ \\
\hline $\mathrm{Cd}$ & 31.010 & 1.82217 & 0.7938 & 29.150 & 1.6982 & 0.8210 \\
$\mathrm{Zn}$ & 18.810 & 0.4207 & 0.8264 & 13.482 & 1.5714 & 0.7237 \\
$\mathrm{Ni}$ & 13.280 & 1.0561 & 0.76508 & 09.120 & 0.2643 & 0.7913 \\
$\mathrm{Cu}$ & 07.810 & 0.7040 & 0.8056 & 11.140 & 0.5803 & 0.8516 \\
$\mathrm{~Pb}$ & 21.395 & 0.2130 & 0.8319 & 15.330 & 0.4511 & 0.8646 \\
\hline
\end{tabular}

Table 4: Freundlich model constants determined from the experiments

\begin{tabular}{|c|c|c|c|c|c|c|}
\hline \multirow[b]{3}{*}{ Elements } & \multicolumn{3}{|c|}{$\begin{array}{l}\text { Adsorbent } \\
\text { (ferric oxide treated) }\end{array}$} & \multicolumn{3}{|c|}{$\begin{array}{l}\text { Adsorbent } \\
\text { (nitric acid treated) }\end{array}$} \\
\hline & \multicolumn{3}{|c|}{$\mathrm{k}_{\mathrm{f}}(\mathrm{mg})^{(1-(1 / \mathrm{i} / \mathrm{n}))}$} & \multicolumn{3}{|c|}{$\mathrm{k}_{\mathrm{f}}(\mathrm{mg})^{(1-(1 / \mathrm{in}))}$} \\
\hline & $\mathrm{n}$ & $\mathrm{g}^{-1} \mathrm{~L}^{(1 / \mathrm{n})}$ & $\mathrm{R}^{2}$ & $\mathrm{n}$ & $\mathrm{g}^{-1} \mathrm{~L}^{(1 / \mathrm{n})}$ & $\mathrm{R}^{2}$ \\
\hline $\mathrm{Cd}$ & 1.8892 & 7.3214 & 0.9210 & 1.9238 & 6.669 & 0.9038 \\
\hline $\mathrm{Zn}$ & 2.0940 & 5.5100 & 0.9743 & 5.03 & 9.770 & 0.9888 \\
\hline $\mathrm{Ni}$ & 4.3440 & 3.6307 & 0.9610 & 4.8782 & 3.3419 & 0.9247 \\
\hline $\mathrm{Cu}$ & 7.6687 & 9.0320 & 0.9608 & 10.5200 & 4.1686 & 0.9755 \\
\hline $\mathrm{Pb}$ & 1.7262 & 5.9937 & 0.95223 & 2.6954 & 6.1645 & 0.9665 \\
\hline
\end{tabular}

Table 5: Flory Huggins model parameters obtained from the experiments Adsorbent (ferric) oxide treated) Adsorbent (nitric acid treated)

\begin{tabular}{lllllll} 
& & & & \\
Elements & $\mathrm{n}_{\mathrm{fh}}$ & $\mathrm{k}_{\mathrm{fh}}$ & $\mathrm{R}^{2}$ & $\mathrm{nfh}$ & $\mathrm{k}_{\mathrm{fh}}$ & $\mathrm{R}^{2}$ \\
\hline $\mathrm{Cd}$ & 0.8715 & 0.8165 & 0.5388 & 1.072 & 0.9913 & 0.6072 \\
$\mathrm{Zn}$ & 1.1382 & 0.7961 & 0.6238 & 0.9471 & 0.4816 & 0.7319 \\
$\mathrm{Ni}$ & 1.944 & 0.2649 & 0.745 & 1.5307 & 0.4161 & 0.5385 \\
$\mathrm{Cu}$ & 1.779 & 0.3031 & 0.573 & 1.3065 & 0.6312 & 0.6686 \\
$\mathrm{~Pb}$ & 1.4154 & 0.5699 & 0.6778 & 2.1282 & 0.5382 & 0.5740 \\
\hline
\end{tabular}

Table 6: Temkin model constants determined from the experiments Adsorbent (ferric oxide treated) Adsorbent (nitric acid treated)

\begin{tabular}{lllllll} 
Elements & $\begin{array}{l}\mathrm{A}_{\mathrm{T}} \\
(\mathrm{L} / \mathrm{mg})\end{array}$ & $\begin{array}{l}\mathrm{B}_{\mathrm{T}} \\
(\mathrm{J} / \mathrm{mol})\end{array}$ & $\mathrm{R}^{2}$ & $\begin{array}{l}\mathrm{A}_{\mathrm{T}} \\
(\mathrm{L} / \mathrm{mg})\end{array}$ & $\begin{array}{l}\mathrm{B}_{\mathrm{T}} \\
(\mathrm{J} / \mathrm{mol})\end{array}$ & $\mathrm{R}^{2}$ \\
\hline $\mathrm{Cd}$ & 27.48 & 8.9133 & 0.7719 & 19.57 & 7.2251 & 0.8136 \\
$\mathrm{Zn}$ & 7.524 & 5.9573 & 0.8843 & 3.1121 & 3.1079 & 0.7474 \\
$\mathrm{Ni}$ & 5.9885 & 1.9857 & 0.6484 & 1.8284 & 4.196 & 0.8208 \\
$\mathrm{Cu}$ & 3.3171 & 1.2255 & 0.7789 & 2.2669 & 1.6513 & 0.7216 \\
$\mathrm{~Pb}$ & 18.978 & 6.738 & 0.8583 & 13.48 & 4.5212 & 0.7847 \\
\hline
\end{tabular}

on the solid surface is physical in nature (Singh et al., 2018). The $A_{T}$ value obtained was highest for cadmium ion for both the $\mathrm{Fe}$ treated and nitric acid treated adsorbent signifying that the cadmium was adsorbed onto the adsorbent surface to the maximum extent compared to the rest of the metal ions (Ray et al., 2018). The free energy factor $\mathrm{E}$ obtained from D-R Model are shown in Table 7. From the values of $\mathrm{E}$ which are lower than $8 \mathrm{~kJ} / \mathrm{mol}$, it can be concluded that the adsorption process follows physical type (Kumar et al., 2018).

It can be observed from Table 3 that the adsorbent impregnated with ferric oxide has larger adsorption capacity in comparison with adsorbent treated with nitric acid. This is because ferric oxide will enhance the adsorbent properties such as surface area and porous nature which are required for the adsorption (He et al., 2018a; Li et al., 2013). The iron treated adsorbent possesses better stability over a long period of time. Various functional groups attached on the adsorbent surface have improved chemical bonding with the adsorbate and the pores present provide larger space for the accommodation of the pollutants (Rule et al., 2014; Zhou et al., 2017). The adsorbent treated with ferric oxide has also advantages that it has high density active sites and larger surface defects which are beneficial for the adsorption (Siddiqui and Chaudhry 2017).

Nitric acid will also have similar influence on the properties of the adsorbent by changing the surface and texture of the material (Hosseini and Hosseini-Bandegharaei 2011; Li et al., 2012). But the above treated adsorbent may not be effective in retaining the chemical species in the pores compared to the adsorbent treated with ferric oxide.

It can be observed from Table 3 that the adsorption capacity of cadmium was maximum compared to other metal ions. This is because of the reasons such as high affinity of the solute towards the adsorbent, ionic properties, electronegativity, covalent index and hydration free energy (Bozorgi et al., 2018; Terdputtakun et al., 2017). In the multicomponent solution lead is another metal which shows the better results next to cadmium. The properties such ass ionic radius, ionic potential and hydration energy of lead are very much suitable in forming the metal adsorbent complex which facilitates adsorption. (Etci et al., 2010; Liu et al., 2019; Loganathan et al., 2018).

The other pollutants zinc, nickel and copper also showed their promising values of adsorption capacity. The possible reasons for these outcomes are size of the solute molecules, its binding energy required for interaction, association with the functional groups present on the adsorbent surface, the type of forces possible between the solute-adsorbent and affinity with the adsorbent surface (Erto et al., 2015; Nashtifan et al., 2017; Zeledon-Toruno et al., 2005) (Table 7).

Interaction mechanism between the pollutants in the solution during adsorption: The pollutant molecules present in the multicomponent solution interacts with each other for the active sites present on the adsorbent surface. The mechanism can be found by comparing the adsorption capacity values of the component (i) in the single component mode qi,s and the capacity of the same component (i) in the multicomponent solution $\left(\mathrm{q}_{\mathrm{i}, \mathrm{m}}\right)$. The different interactions between the adsorbate and adsorbent are: 
Table 7: Dubinin-Radushkevich model parameters calculated for both the adsorbents

\begin{tabular}{|c|c|c|c|c|c|c|c|c|}
\hline \multirow[b]{2}{*}{ Elements } & \multicolumn{4}{|c|}{ Adsorbent (ferric oxide treated) } & \multicolumn{4}{|c|}{ Adsorbent (nitric acid treated) } \\
\hline & $\mathrm{q}_{\mathrm{dr}}(\mathrm{mg} / \mathrm{g})$ & $\beta(\mathrm{mol})^{2} \mathrm{~kJ}^{2}$ & $\mathrm{E}(\mathrm{kJ} / \mathrm{mol})$ & $\mathrm{R}^{2}$ & $\mathrm{q}_{\mathrm{dr}}(\mathrm{mg} / \mathrm{g})$ & $\beta(\mathrm{mol})^{2} \mathrm{~kJ}^{2}$ & $\mathrm{E}(\mathrm{kJ} / \mathrm{mol})$ & $\mathrm{R}^{2}$ \\
\hline $\mathrm{Cd}$ & 15.16 & $1.3 \mathrm{E}-5$ & 0.196 & 0.7039 & 12.82 & $1.09 \mathrm{E}-5$ & 0.214 & 0.7763 \\
\hline $\mathrm{Zn}$ & 9.3418 & $9 \mathrm{E}-6$ & 0.235 & 0.6092 & 8.224 & $7.61 \mathrm{E}-6$ & 0.256 & 0.6512 \\
\hline $\mathrm{Ni}$ & 6.4475 & $2.1 \mathrm{E}-6$ & 0.487 & 0.7489 & 2.821 & $1.09 \mathrm{E}-6$ & 0.677 & 0.5909 \\
\hline $\mathrm{Cu}$ & 4.4754 & $3.32 \mathrm{E}-6$ & 0.389 & 0.8036 & 3.198 & $2.13 \mathrm{E}-6$ & 0.484 & 0.6272 \\
\hline $\mathrm{Pb}$ & 7.4283 & $5.2 \mathrm{E}-6$ & 0.310 & 0.6708 & 6.745 & $6.9 \mathrm{E}-6$ & 0.2269 & 0.7487 \\
\hline
\end{tabular}

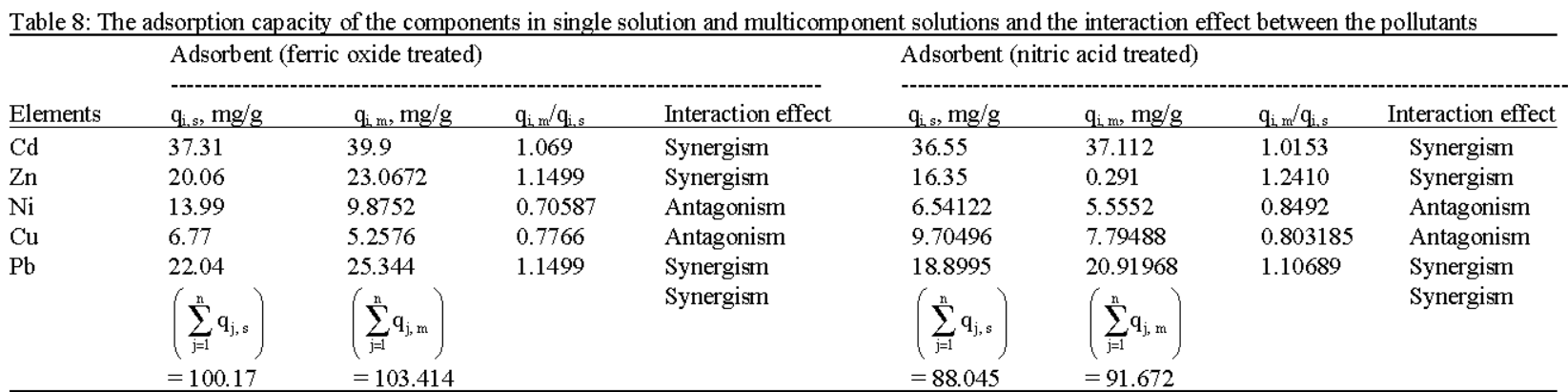

Synergism: The adsorption capacity of a component enhances because of the existence of other components in the solution $\left(\mathrm{q}_{\mathrm{i}, \mathrm{m}}>\mathrm{q}_{\mathrm{i}, \mathrm{s}}\right)$.

Antagonistic interaction: The adsorption capacity of a component is suppressed due to the presence of other solute molecules in the solution $\left(\mathrm{q}_{\mathrm{i}, \mathrm{m}}<\mathrm{q}_{\mathrm{i}, \mathrm{s}}\right)$.

Non interaction effect: The adsorption capacity of a component is not effected by the presence of the other components in the system $\left(\mathrm{q}_{\mathrm{i}, \mathrm{m}}=\mathrm{q}_{\mathrm{i}, \mathrm{s}}\right.$ ) (Singh et al., 2018; Terdputtakun et al., 2017).

The interaction effect for the overall system can also be found by comparing the total adsorption capacity of all the components in the single solution mode $\left(\sum_{j=1}^{n} q_{j, s}\right)$ and in the multicomponent solution $\left(\Sigma_{j=1)}{ }^{n}\right) q_{(j, m)}$ which are found as using:

$$
\begin{gathered}
\sum_{j=1}^{n} q_{j, s}=q_{i, s}+q_{j, s}+q_{k, s}+, \ldots, \\
\sum_{j=1}^{n} q_{j, m}=q_{i, m}+q_{j, m}+q_{k, m}+, \ldots,
\end{gathered}
$$

The system shows synergistic interaction as the value of $\left(\Sigma_{j=1}^{n}\left(q_{j, m}\right)>\Sigma_{j}{ }^{n}=1\left(q_{j}, s\right)\right.$. But antagonistic behavior is observed if the value of $\left(\Sigma_{j=1}^{n}\left(q_{j, m}\right)\right.$ $<\Sigma_{\mathrm{j}=1}^{\mathrm{n}}\left(\mathrm{q}_{\mathrm{j}, \mathrm{s}}\right)$ (Bohli et al., 2017; Hameed et al., 2008).

Interaction effects in the multicomponent solution: The calculated adsorption capacities of the components in the single solution and multicomponent solution mode for both ferric oxide treated solution and nitric acid solution are shown in Table 8 . It was observed that the total the total adsorption capacity:

$$
\left(\sum_{j=1}^{n} q_{j, m}\right)
$$

For the combined system was more than the total adsorption capacity:

$$
\left(\sum_{j=1}^{\mathrm{n}} \mathrm{q}_{\mathrm{j}, \mathrm{s}}\right)
$$

In the single solution mode which exhibits synergistic type of behaviour. The possible reason for the above interaction is because of the adsorbate such as molecular polarity, reduction potential, ionic size, molecular weight and the surface properties and the structure of the adsorbent and the functional groups present on the surface (He et al., 2018b; Lu et al., 2013; Wang et al., 2019).

\section{CONCLUSION}

The tea fiber waste was used effectively as an adsorbent for removing the pollutants cadmium, nickel, zinc, copper and lead from wastewater. The surface properties of the adsorbent were enhanced by treating the material with ferric oxide and nitric acid. From the FTIR and SEM analysis the functional groups on the adsorbent surface were detected and the surface morphology was studied. The isotherm data were fitting best with the Freundlich model signifying that adsorption process is 
physical in nature and takes place in multilayers. The existence of physical type of adsorption was also supported by the values of $\mathrm{n}$ and $\mathrm{E}$. The multicomponent studies resulted in synergistic types of behavior for cadmium, zinc and lead and antagonistic nature for nickel and copper. The maximum adsorption capacity values obtained for different metals were promising. Finally, it is concluded that the tea fiber waste is efficient for the preparation of the adsorbent and for removing toxic metals from wastewater.

\section{ACKNOWLEDGEMENT}

The research gratefully acknowledge the IAESTE India LC Manipal for the IAESTE internship student exchange program.

\section{REFERENCES}

APHA, AWWA and WEF., 1989. Standard Methods for the Examination of Water and Wastewater. 17th Edn., American Public Health Association, American Water Works Association and Water Pollution Control Federation, Washington, DC., USA., ISBN-13: 9780875531618, Pages: 1391

Achak, M., A. Hafidi, N. Ouazzani, S. Sayadi and L. Mandi, 2009. Low cost biosorbent banana peel for the removal of phenolic compounds from olive mill wastewater: Kinetic and equilibrium studies. J. Hazard. Mater., 166: 117-125.

Anirudhan, T.S., S.S. Sreekumari and C.D. Bringle, 2009. Removal of phenols from water and petroleum industry refinery effluents by activated carbon obtained from coconut coir pith. Adsorpt., 15: 439-451.

Anna, B., M. Kleopas, S. Constantine, F. Anestis and B. Maria, 2015. Adsorption of $\mathrm{Cd}$ (II), $\mathrm{Cu}$ (II), $\mathrm{Ni}$ (II) and $\mathrm{Pb}$ (II) onto natural bentonite: Study in mono-and multi-metal systems. Environ. Earth Sci., 73: 5435-5444.

Arami, M., N.Y. Limaee, N.M. Mahmoodi and N.S. Tabrizi, 2005. Removal of dyes from colored textile wastewater by orange peel adsorbent: Equilibrium and kinetic studies. J. Colloid Interface Sci., 288: 371-376.

Arim, A.L., G. Guzzo, M.J. Quina and L.M. Gando-Ferreira, 2018. Single and binary sorption of $\mathrm{Cr}$ (III) and $\mathrm{Ni}$ (II) onto modified pine bark. Environ. Sci. Pollut. Res., 25: 28039-28049.

Babaee, Y., C.N. Mulligan and M.S. Rahaman, 2018. Removal of arsenic (III) and arsenic (V) from aqueous solutions through adsorption by $\mathrm{Fe} / \mathrm{Cu}$ nanoparticles. J. Chem. Technol. Biotechnol., 93: 63-71.
Baig, K.S., H.D. Doan and J. Wu, 2009. Multicomponent isotherms for biosorption of $\mathrm{Ni}^{2+}$ and $\mathrm{Zn}^{2+}$. Desalin., 249: 429-439.

Belyakova, L.A., D.Y. Lyashenko and A.N. Shvets, 2014. Sorption of Cd (II) from multicomponent nitrate solutions by functional organosilicas. J. Water Chem. Technol., 36: 56-61.

Bohli, T., A. Ouederni and I. Villaescusa, 2017. Simultaneous adsorption behavior of heavy metals onto microporous olive stones activated carbon: Analysis of metal interactions. Euro Mediterr. J. Environ. Integr., 2: 1-15.

Bozorgi, M., S. Abbasizadeh, F. Samani and S.E. Mousavi, 2018. Performance of synthesized cast and electrospun $\mathrm{PVA} / \mathrm{chitosan} / \mathrm{ZnO}-\mathrm{NH}_{2}$ nanoadsorbents in single and simultaneous adsorption of cadmium and nickel ions from wastewater. Environ. Sci. Pollut. Res., 25: 17457-17472.

Chatterjee, S., I. Sivareddy and S. De, 2017. Adsorptive removal of potentially toxic metals (Cadmium, Copper, Nickel and Zinc) by chemically treated laterite: Single and multicomponent batch and column study. J. Environ. Chem. Eng., 5: 3273-3289.

Costa, C.S.D., B.G.M. Queiroz, R. Landers, M.G.C. Da Silva and M.G.A. Vieira, 2018. Equilibrium study of binary mixture biosorption of $\mathrm{Cr}$ (III) and $\mathrm{Zn}$ (II) by dealginated seaweed waste: Investigation of adsorption mechanisms using X-ray photoelectron spectroscopy analysis. Environ. Sci. Pollut. Res., 1: 1-11.

Da-Gama, B.M.V., G.E. Do-Nascimento, D.C.S. Sales, J.M. Rodriguez-Diaz and C.M.B. De Menezes Barbosa et al., 2018. Mono and binary component adsorption of phenol and cadmium using adsorbent derived from peanut shells. J. Cleaner Prod., 201: 219-228.

Du, H., Q. Huang, C.L. Peacock, B. Tie and M. Lei et al., 2018. Competitive binding of $\mathrm{Cd}, \mathrm{Ni}$ and $\mathrm{Cu}$ on goethite organo-mineral composites made with soil bacteria. Environ. Pollut., 243: 444-452.

Elizalde-Gonzalez, M.P. and V. Hernandez-Montoya, 2009. Guava seed as an adsorbent and as a precursor of carbon for the adsorption of acid dyes. Bioresour. Technol., 100: 2111-2117.

Erto, A., F. Di-Natale, D. Musmarra and A. Lancia, 2015. Modeling of single and competitive adsorption of Cadmium and Zinc onto activated Carbon. Adsorpt., 21: 611-621.

Etci, O., N. Bektas and M.S. Oncel, 2010. Single and binary adsorption of lead and cadmium ions from aqueous solution using the clay mineral beidellite. Environ. Earth Sci., 61: 231-240. 
Foo, K.Y. and B.H. Hameed, 2010. Insights into the modeling of adsorption isotherm systems. Chem. Eng. J., 156: 2-10.

Gupta, A. and C. Balomajumder, 2017. Statistical optimization of process parameters for the simultaneous adsorption of $\mathrm{Cr}(\mathrm{VI})$ and phenol onto Fe-treated tea waste biomass. Appl. Water Sci., 7: 4361-4374.

Hameed, B.H., 2009. Spent tea leaves: A new nonconventional and low-cost adsorbent for removal of basic dye from aqueous solutions. J. Hazard. Mater., 161: 753-759.

Hameed, B.H., I.A.W. Tan and A.L. Ahmad, 2008. Adsorption isotherm, kinetic modeling and mechanism of 2, 4, 6-trichlorophenol on coconut husk-based activated carbon. Chem. Eng. J., 144: 235-244.

He, R., Z. Peng, H. Lyu, H. Huang and Q. Nan et al., 2018b. Synthesis and characterization of an iron-impregnated biochar for aqueous arsenic removal. Sci. Total Environ., 612: 1177-1186.

He, S., Y. Li, L. Weng, J. Wang and J. He et al., $2018 \mathrm{a}$. Competitive adsorption of $\mathrm{Cd}^{2+}, \mathrm{Pb}^{2+}$ and $\mathrm{Ni}^{2+}$ onto $\mathrm{Fe}^{3+}$-modified argillaceous limestone: Influence of $\mathrm{pH}$, ionic strength and natural organic matters. Sci. Total Environ., 637: 69-78.

He, X., Y. Zhang, M. Shen, Y. Tian and K. Zheng et al., 2017. Vermicompost as a natural adsorbent: Evaluation of simultaneous metals $(\mathrm{Pb}, \mathrm{Cd})$ and tetracycline adsorption by sewage sludge-derived vermicompost. Environ. Sci. Pollut. Res., 24: 83758384.

Hossain, M.A., H.H. Ngo, W.S. Guo, L.D. Nghiem and F.I. Hai et al., 2014. Competitive adsorption of metals on cabbage waste from multi-metal solutions. Bioresour. Technol., 160: 79-88.

Hosseini, M.S. and A. Hosseini-Bandegharaei, 2011. Comparison of sorption behavior of Th(IV) and U (VI) on modified impregnated resin containing quinizarin with that conventional prepared impregnated resin. J. Hazard. Mater., 190: 755-765.

Iqbal, M., A. Saeed and S.I. Zafar, 2009. FTIR spectrophotometry, kinetics and adsorption isotherms modeling, ion exchange and EDX analysis for understanding the mechanism of $\mathrm{Cd}^{2+}$ and $\mathrm{Pb}^{2+}$ removal by mango peel waste. J. Hazard. Mater., 164 : 161-171.

Jung, H., S. Jeon, D.H. Jo, J. Huh and S.H. Kim, 2017. Effect of crosslinking on the $\mathrm{CO}_{2}$ adsorption of polyethyleneimine-impregnated sorbents. Chem. Eng. J., 307: 836-844.
Kakavandi, B., A.J. Jafari, R.R. Kalantary, S. Nasseri and A. Esrafili et al., 2016. Simultaneous adsorption of lead and aniline onto magnetically recoverable Carbon: Optimization, modeling and mechanism. J. Chem. Technol. Biotechnol., 91: 3000-3010.

Kavand, M., T. Kaghazchi and M. Soleimani, 2014. Optimization of parameters for competitive adsorption of heavy metal ions $\left(\mathrm{Pb}^{+2}, \mathrm{Ni}^{+2}, \mathrm{Cd}^{+2}\right)$ onto activated Carbon. Korean J. Chem. Eng., 31: 692-700.

Kilic, M., E. Apaydin-Varol and A.E. Putun, 2011. Adsorptive removal of phenol from aqueous solutions on activated carbon prepared from tobacco residues: Equilibrium, kinetics and thermodynamics. J. Hazard. Mater., 189: 397-403.

Kumar, M., H.S. Dosanjh and H. Singh, 2018. Magnetic Zinc ferrite-chitosan bio-composite: Synthesis, characterization and adsorption behavior studies for cationic dyes in single and binary systems. J. Inorg. Organomet. Polym. Mater., 28: 880-898.

Li, G., J. Lan, J. Liu and G. Jiang, 2013. Synergistic adsorption of as (V) from aqueous solution onto mesoporous silica decorated orderly with $\mathrm{Al}_{2} \mathrm{O}_{3}$ and $\mathrm{Fe}_{2} \mathrm{O}_{3}$ nanoparticles. J. Colloid Interface Sci., 405: 164170 .

Li, H., J. Liu, X. Gao, C. Liu and L. Guo et al., 2012. Adsorption behavior of indium (III) on modified solvent impregnated resins (MSIRs) containing secoctylphenoxy acetic acid. Hydrometallurgy, 121: 6067.

Li, J.M., X. G. Meng, C.W. Hu and J. Du, 2009. Adsorption of phenol, p-chlorophenol and p-nitrophenol onto functional chitosan. Bioresour. Technol., 100: 1168-1173.

Liu, J., C. Hu and Q. Huang, 2019. Adsorption of $\mathrm{Cu}^{2+}$, $\mathrm{Pb}^{2+}$ and $\mathrm{Cd}^{2+}$ onto oiltea shell from water. Bioresour. Technol., 271: 487-491.

Liu, Q.S., T. Zheng, P. Wang, J.P. Jiang and N. Li, 2010. Adsorption isotherm, kinetic and mechanism studies of some substituted phenols on activated carbon fibers. Chem. Eng. J., 157: 348-356.

Soganathan, P., W.G. Shim, D.P. Sounthararajah, M. Kalaruban and T. Nur et al., 2018. Modelling equilibrium adsorption of single, binary and ternary combinations of $\mathrm{Cu}, \mathrm{Pb}$ and $\mathrm{Zn}$ onto granular activated carbon. Environ. Sci. Pollut. Res., 25: 16664-16675.

Lu, M., Y.G. Liu, X.J. Hu, Y. Ben and X.X. Zeng et al., 2013. Competitive adsorption of $\mathrm{Cu}$ (II) and $\mathrm{Pb}$ (II) ions from aqueous solutions by Ca-alginate immobilized activated carbon and Saccharomyces cerevisiae. J. Cent. South Univ., 20: 2478-2488. 
Mohammad-Rezaei, R. and M. Jaymand, 2019. Graphene quantum dots coated on quartz sand as efficient and low-cost adsorbent for removal of $\mathrm{Hg}^{2+}$ and $\mathrm{Pb}^{2+}$ from aqueous solutions. Environ. Prog. Sustainable Energy, 38: S24-S31.

Mohan, S.M., 2014. Simultaneous adsorption and biodegradation process in a SBR for treating wastewater containing heavy metals. J. Environ. Eng., 140: 04014008-04014008.

Moreno-Castilla, C., 2004. Adsorption of organic molecules from aqueous solutions on carbon materials. Carbon, 42: 83-94.

Nashtifan, S.G., A. Azadmehr and A. Maghsoudi, 2017. Comparative and competitive adsorptive removal of $\mathrm{Ni}^{2+}$ and $\mathrm{Cu}^{2+}$ from aqueous solution using iron oxide-vermiculite composite. Appl. Clay Sci., 140: 38-49.

Niu, Z., Q. Xue, S. Qi, Y. Guo and H. Chen, 2018. Effect of multifactors interaction on competitive adsorption of $\mathrm{Zn}^{2+}$ and $\mathrm{Cd}^{2+}$ by response surface methodology. Environ. Earth Sci., 77: 1-12.

Omidinasab, M., N. Rahbar, M. Ahmadi, B. Kakavandi and F. Ghanbari et al., 2018. Removal of vanadium and palladium ions by adsorption onto magnetic chitosan nanoparticles. Environ. Sci. Pollut. Res., 25: 3426234276.

Park, K.H., M.S. Balathanigaimani, W.G. Shim, J.W. Lee and H. Moon, 2010. Adsorption characteristics of phenol on novel corn grain-based activated carbons. Microporous Mesoporous Mater., 127: 1-8.

Prelot, B., M. AraIssi, P. Gras, F. Marchandeau and J. Zajac, 2018. Contribution of calorimetry to the understanding of competitive adsorption of calcium, strontium, barium and cadmium onto 4A type zeolite from two-metal aqueous solutions. Thermochim. Acta, 664: 39-47.

Rathinam, K., P. Jayaram and M. Sankaran, 2019. Synthesis and characterization of magnetic chitin composite and its application towards the uptake of $\mathrm{Pb}$ (II) and $\mathrm{Cd}$ (II) ions from aqueous solution. Environ. Progr. Sustainable Energy, 38: S288-S297.

Ray, J., S. Jana, S.K. Bhanja and T. Tripathy, 2018. Efficient removal $\mathrm{f}$ Co (II), $\mathrm{Ni}$ (II) and $\mathrm{Zn}$ (II) metal ions from binary and ternary solutions using a $\mathrm{pH}$ responsive bifunctional graft copolymer. Colloid Polym. Sci., 296: 1275-1291.

Rule, P., K. Balasubramanian and R.R. Gonte, 2014. Uranium (VI) remediation from aqueous environment using impregnated cellulose beads. J. Environ. Radioact., 136: 22-29.
Salman, J.M. and B.H. Hameed, 2010. Removal of insecticide car-bofuran from aqueous solutions by banana stalks activated carbon. J. Hazard. Mater., 176: 814-819.

Sarkar, M. and P.K. Acharya, 2006. Use of fly ash for the removal of phenol and its analogues from contaminated water. Waste Manage., 26: 559-570.

Sathishkumar, M., A.R. Binupriya, D. Kavitha and S.E. Yun, 2007. Kinetic and isothermal studies on 2, 4-dichlorophenol by palm pith carbon. Bioresour. Technol., 98: 866-873.

Shirani, M., A. Semnani, H. Haddadi and S. Habibollahi, 2014. Optimization of simultaneous removal of methylene blue, crystal violet and fuchsine from aqueous solutions by magnetic $\mathrm{NaY}$ zeolite composite. Water Air Soil Pollut., 225: 1-15.

Siddiqui, S.I. and S.A. Chaudhry, 2017. Iron oxide and its modified forms as an adsorbent for arsenic removal: A comprehensive recent advancement. Process Saf. Environ. Prot., 111: 592626.

Singh, N., A. Kumari and C. Balomajumder, 2018. Modeling studies on mono and binary component biosorption of phenol and cyanide from aqueous solution onto activated carbon derived from saw dust. Saudi J. Biol. Sci., 25: 1454-1467.

Sreedharan, V., K.V. Krithishna and P.V. Nidheesh, 2017. Removal of chromium and iron from real textile wastewater by Sorption on Soils. J. Hazard. Toxic Radioactive Waste, Vol. 21,

Sukpreabprom, H., O.A. Arqueropanyo, W. Naksata, P. Sooksamiti and S. Janhom, 2015. Single and binary adsorption of $\mathrm{Cd}$ (II) and $\mathrm{Zn}$ (II) ions from aqueous solutions onto bottom ash. Korean J. Chem. Eng., 32: 896-902.

Terdputtakun, A., O.A. Arqueropanyo, P. Sooksamiti, S. Janhom and W. Naksata, 2017. Adsorption isotherm models and error analysis for single and binary adsorption of $\mathrm{Cd}$ (II) and $\mathrm{Zn}$ (II) using leonardite as adsorbent. Environ. Earth Sci., 76: 777-777.

Verma, S.P. and B. Sarkar, 2018. Simultaneous removal of Cd (II) and p-cresol from wastewater by micellar-enhanced ultrafiltration using rhamnolipid: Flux decline, adsorption kinetics and isotherm studies. J. Environ. Manage., 213: 217-235.

Wang, D., J. Li, Z. Xu, Y. Zhu and G. Chen, 2019. Preparation of novel flower-like $\mathrm{BiVO}_{4} / \mathrm{Bi}_{2} \mathrm{Ti}_{2} \mathrm{O}_{7} / \mathrm{Fe}_{3} \mathrm{O}_{4}$ for simultaneous removal of tetracycline and $\mathrm{Cu}^{2+}$ : Adsorption and photocatalytic mechanisms. J. Colloid Interface Sci., 533: 344-357. 
Wang, L.P. and Y.J. Chen, 2018. Sequential precipitation of iron, copper and zinc from wastewater for metal recovery. J. Environ. Eng., 145: 04018130-04018130.

Werkneh, A.A., E.R. Rene and P.N. Lens, 2018. Simultaneous removal of selenite and phenol from wastewater in an upflow fungal pellet bioreactor. J. Chem. Technol. Biotechnol., 93: 1003-1011.

Xu, Z., K. Wang, Q. Liu, F. Guo and Z. Xiong et al., 2018. A bifunctional adsorbent of silica gel-immobilized schiff base derivative for simultaneous and selective adsorption of $\mathrm{Cu}$ (II) and $\mathrm{SO}_{4}{ }^{2-}$. Sep. Purif. Technol., 191: $61-74$.
Yousef, R.I., B. El-Eswed and A.A.H. Al-Muhtaseb, 2011. Adsorption characteristics of natural zeolites as solid adsorbents for phenol removal from aqueous solutions: Kinetics, mechanism and thermodynamics studies. Chem. Eng. J., 171: 1143-1149.

Zeledon-Toruno, Z., C. Lao-Luque and M. Sole-Sardans, 2005. Nickel and Copper removal from aqueous solution by an immature coal (leonardite): Effect of $\mathrm{pH}$, contact time and water hardness. J. Chem. Technol. Biotechnol., 80: 649-656.

Zhou, Z., Y.G. Liu, S.B. Liu, H.Y. Liu and G.M. Zeng et al., 2017. Sorption performance and mechanisms of arsenic (V) removal by magnetic gelatin-modified biochar. Chem. Eng. J., 314: 223-231. 